\title{
The New Gilded Age: We've Seen It All Before
}

\section{Wight Martindale Jr.}

The thesis here is that the period in American history between the end of the Civil War and sometime in the 1890's-which we know as the Gilded Age-is being played out right now. Today's progressive rise to power has brought with it the desire to redesign American society, replacing the ideal of upward individual mobility with a birth-to-death entitlement state. The educational establishment, with its latest bright idea, the “1619 Project," enthusiastically rewrites America's founding history. The self-appointed intellectual and political elite tolerates no debate. Rural America, when not being mocked, is marginalized, and old-fashioned common sense is hard to find. But we've been there before.

Four marks of the original Gilded Age are clear.

1) Wealth. The Gilded Age was a time of unparalleled wealth creationfrequently in a single generation. The opening of settlements in the West, the Transcontinental Railroad, the growth of industry and the productive capacity of farming, and the huge flow of European human and financial capital, all of which took place at a rate never seen before in all of world history.

The parallels today are not hard to find.

Over 35 million immigrants have flowed into the U.S. between 1980 and 2020. The enormous aggregation of wealth in the technology sector stand before us every day. (Bill Gates, age 65, Microsoft, net worth $\$ 130$ billion; Sergey Brin, $\$ 100$ billion and Larry Page, $\$ 120$ billion both at Google and both age 47; and Mark Zuckerberg, age 38, Facebook, \$118 billion). Add to this Jeff Bezos (age 56, Amazon, $\$ 113$ billion, plus his divorced wife, Mackinzie, $\$ 61$ billion) and Elon Musk (\$157.6 billion, age 49). In 2021, Forbes magazine calculated that over the past twelve months 493 new billionaires were created worldwide-one every seventeen hours. The nearly instant wealth they have achieved dwarfs the

\footnotetext{
Wight Martindale Jr. has been an adjunct professor in the Honors Program at Villanova University; wight. martindale@gmail.com. A former vice president at Lehman Brothers, he is the author of Inside the Cage: A Season at West 4th Street's Legendary Tournament (Simon and Schuster, 2005) and Don Quixote Goes to College: From the Trading Floor to the Classroom, A Memoir on Education (privately printed, 2013). He last appeared in these pages with "Creating a Middle School American History Program," (Winter, 2020).
} 
titans of the Gilded Age-Andrew Carnegie (steel), J. P. Morgan (banking), or Leland Stanford (railroads).

2) Corruption. Gilded Age politics was famously corrupt. Everything and everyone was for sale-North and South, city and country. This became evident in the North during the Civil War, when the federal government gave away millions of acres to the railroads. Corruption reappeared in the Reconstruction governments in the south, continued to haunt Grant's eight years in office, and flourished again in the blatantly dishonest election of Rutherford Hayes in 1877.

Today. The money spent in just the 2020 political campaigns have entered a new order of magnitude. This money does not come entirely from individuals; it comes from organizations (various labor unions, universities, other non-profits, and private businesses) that expect to benefit from their contributions.

Consider: In the 2020 presidential election Michael Bloomberg put $\$ 100$ million into the Florida race; Jamie Harrison received $\$ 108$ million in his attempt to defeat Lindsey Graham in South Carolina. In the Georgia senate races of 2021 the two candidates Kelly Loeffler and Richard Warnock together received \$363 million only to be topped in the David Perdue-Jon Ossoff race, which raised $\$ 470$ million. In 2014 total spending of both candidates in the Georgia senate race was $\$ 29$ million.

Remember earmarks? They're back (March, 2021). Most of what were thought to be the great scandals in the Grant administration have become commonplace procedures. Is anyone surprised that the states of Maryland $\left(2^{\text {nd }}\right)$ and Virginia $\left(9^{\text {th }}\right)$, which border Washington D. C., are both among the top ten of American states with highest ratio of millionaire households per capita in 2020? Washington is for sale, and the prize is your tax dollars.

Finally, reflect on the 2021, \$1.9 trillion Covid relief bill, where less than $\$ 600$ billion is spent on Covid relief, the rest being compensation for free-spending politicians and their supporters.

3) A new elite. From the intellectual community there emerged in the $1880 \mathrm{~s}$ a fierce, puritanical self-righteousness which had begun with abolition, moved on to temperance, and soon extended through women's suffrage to novel spiritualists, various forms of utopias, and a general disgust with America. The disenchantment of the intellectuals that began with the Gilded Age was later termed the "adversary culture" by critic Lionel Trilling, and provided a rich target for the scorn of resurgent populists like William Jennings Bryan. 
Power is what the nihilist elites of the 1890s wanted most. Sound familiar? Today the elite finds itself vehemently opposed to any sort of populist dissent. The list of "deplorables” keeps growing. Untouchable priorities remain global warming, public over private education, less vigorous law enforcement, open borders, and accelerated racial preferences. America is once again seen as a failed nation in need of radical new leaders-the reformers themselves, of course. History is bunk.

4) Marginalization of blacks. Finally, and perhaps most sadly, the political prospects of the freedmen continued to darken. The party to which blacks aligned themselves never felt their well-being was essential to its own interests. Black support was too easy. The Northern elites acquiesced to the segregated rule in the South and paid only lip-service to black political and economic needs in the North.

Millions of blacks today are successful in business, the professions, government, and the non-profit sector, but many still struggle. As during the Gilded Age, the party to which blacks have thrown their support takes that support for granted, and prioritize globalist policies like off-shoring of jobs and mass legal and illegal immigration, and teacher union opposition to school choice.

Can the critiques of the original Gilded Age help us understand what is going on today? In a 1960 essay by C. Vann Woodward, “The Southern Critique for the Gilded Age," Woodward pointed to three important works of the time: Herman Melville's philosophical poem Clarel (1876), Henry Adams's satirical novel Democracy (1880), and Henry James's novel, The Bostonians (1886). All of these writers acknowledged the relevance of the Southern tradition in their critique of American society, and each came from authentic Yankee heritage. In each of these works a veteran of the Confederate army is introduced in a sympathetic role.

These critiques offered over 135 years ago have become relevant today, but one stands out, The Bostonians. James was in no way a Southern sympathizer nor had he ever ventured south of the Potomac. But the central male figure in the story is Basil Ransom, a handsome, intelligent, thirty year-old son of a plantation owner, a man who had fought in the civil war, and had "tasted all the cruelty of defeat." He had recently headed north with $\$ 50$ in his pocket to practice law in New York, where he finds the victorious, prosperous Northerners working to implement their vision of human progress. 
The book's central character is a woman with a great will to power, Olive Chancellor, a Boston bluestocking reformer described by her more conventional sister as a champion of prohibition, women's rights, mesmerism, various spiritualisms -in short, "a female Jacobin, a nihilist. Whatever is, is wrong. ... She would reform the solar system if she could get hold of it." Although not yet thirty, Olive never laughs and is without charm. Ransom is a distant cousin of hers, so she invites him for dinner and a meeting with her friends.

These friends include Miss Birdseye, an older woman and a celebrity in this circle, who had organized that evening a group of people "interested in new ideas." She is described with Dickensian absurdity: "She belonged to the Short Skirts League, for she belonged to any and every league that had been founded for almost any purpose whatever. ... She is confused, entangled ... one whose charity begins at home and ended nowhere, and who knew less about her fellow creatures, if possible, after fifty years of humanitarian zeal than the day she had first gone into the field to testify against the iniquity of most arrangements."

Speaking that evening was the majestic person of Mrs. Farrinder, “a copious, handsome woman," fashionably dressed, who spoke "with great slowness and distinctness, and evidently a high sense of responsibility." She thrives on controversy, declaring "I am only myself when I see prejudice, when I see bigotry, when I see injustice, when I see conservatism massed before me like an army. Then ... I imagine myself as Napoleon Bonaparte must have felt on the eve of one of his great victories." A useful woman, Olive Chancellor felt, but a touch provincial, coming, as she did, from Roxbury.

There is also a "little medical lady," Dr. Prance. She is well-meaning, but she strikes Ransom as "a perfect example of the Yankee female . . the type produced by the New England school system, the Puritan code, the uncongenial climate, the absence of chivalry."

Enter into the scene a beautiful, charismatic young woman, Verena Tarrant, with a genius for inspirational speaking, the daughter of a "mesmeric healer." But the family is poor. Olive immediately realizes that Verena could become a force for her own brand of feminism so she takes her into her home, pays off her useless father so that he will stay out of the way, and begins to train her properly. Olive quickly recognizes that "left to herself, she (Verena) was not always thinking of the unhappiness of women."

Ransom is likewise attracted to Verena, but he wants her for his own kind of traditional, passionate, and familial love. Olive quickly realizes that Ransom 
is a deadly enemy. As she explains to Verena, "I am not the least afraid of your marrying a repulsive man, your danger would come from an attractive one."

Thus, they struggle over Verena. It's the Bostonians versus Mississippi.

Earlier in the story we saw how the conflict would develop when Olive asks Ransom, “Don't you care for human progress?” In a slow, courteous, Southern drawl he replies, "I don't know-I never saw any."

Verena is attracted to Ransom, but also fascinated by his perspective-his ideas about women, progress, family, tradition, his love of the land in which he was born. She had never before encountered such cynicism and sarcasm directed against the most progressive ideas of her age.

Some very good readers (Leon Edel among them) feel that Ransom is like Olive, a "profound egoist who does not love Verena for herself," but simply wants to triumph ideologically. But this reading is open to question. Ransom's desperation to see her under any circumstances, his recognition that Verena was "unspeakably attractive," and his frank admission that he was quickly falling in love with her argue that for Ransom and for Verena, this was the real thing, as James intended.

Of course the novel is about the Bostonians, and so James draws us back to that subject. Ransom revisits Verena on Cape Cod and proposes marriage, but he asks that she give up her speaking life. Verena is terribly torn; Olive has given her so much. In the final chapter, crippled by her tortuous ordeal, she abandons a huge Boston audience which awaits her as, cloaked and tearful, she escapes with her lover to New York, where they will begin a new life together.

Ransom is aware that the South had been tragically deceived by its elite, but he asks, is not the new North of Boston and New York facing the same threat from their elite? Henry James's gripe with the North was that unlike the South, it had no traditions, no history, no attachment to the land that comes with agrarian life. He said of big money Northerners that "what you are reduced to for importance is the present, squaring itself between an absurd future and an absent past." For Ransom the past matters.

Is this not a brief, brilliant summation of the blue state, wealthy suburb mentality and their public schools today? Erase history. Never reveal to parents what books are actually being read-there is no core. Erase the high school mascot ("Red Raiders," Radnor, PA) that has served for over a hundred years. In this Philadelphia suburb the citizens and the students oppose the change of 
mascot-but the faculty and the school board know better. Their end-product is chaos.

Perhaps the hottest sports talk show now is Paul Finebaum's program about the SEC, the dreaded Southeastern Conference. This is a world in which entire states are united, games are attended by three and often four generations, results count, and young people-and their coaches-are well paid, revered, and cared for. This family feel has spread to other sports. The SEC TV station devotes hundreds of hours a year to women's gymnastics, softball, volleyball, and women's basketball, essentially team sports. Why is it that the most insightful-and entertaining-basketball commentator today is Charles Barkley, former NBA star, from Leeds, Alabama?

Of course it's not just Southern men. From 2013 to 2018 Joanna Gaines and her husband Chip had HGTV's most popular show, The Fixer-Upper. In Waco, Texas, with warmth and charm, they helped people without a ton of money make a nice home out of something bare and boring. They don't build mega-mansions for the newly rich. The couple's five children regularly appear on the show. Joanna's “Magnolia Table” cookbook is a nationwide best seller which celebrates the comfort of home cooked meals and time together in the kitchen. Both Joanna and Chip grew up in Waco and attended Baylor University. Whether they know it or not, they are selling the South.

It is also worth noting that Associate Justice Amy Coney Barrett grew up in New Orleans and attended tiny Rhodes College in Memphis where she was an English major.

Woodward spent a lifetime explaining that the Southern perspective is not like that of Hollywood or the Northeast, both of which are very wealthy and unbowed. He recognized that by the middle of the nineteenth century the South had become blind to its own evils. In foolishly fighting to defend their way of life, Southerners took refuge in a dream world, and bullied others into accepting their castle in the sky. They paid a very dear price for bad leadership.

The shattering of this dream-with humiliation and defeat-was a harsh education and it did not engender a race of utopians; Southerners respect results, not chatter. They admire physical toughness, they are instinctively cautious and more sensitive to the reality of evil than the dream of perfection. Ralph Waldo Emerson has no place here. The Bostonians of James's novel wanted to believe they were all right all of the time; from experience, Southerners knew better. 
So where does this leave us? The Gilded Age ended in a financial "panic” in 1893 followed by a four-year depression unlike any that had preceded it. The economic stratification that intensified in those years led to progressive-era reforms that slowly shifted power away from the "Robber Barons." It is not possible to say what the future holds, and the possibility of a strong economy and a soft landing following the pandemic shutdowns of 2020 can't be ruled out. Over the course of 2020, with Covid and a 2 percent decline in GDP, American household net worth rose by 10 percent to $\$ 130$ trillion, a record high. Financial markets are much improved; we may stay gilded for quite a while longer.

Nevertheless, we should observe how the previous boom ended.

The standard history says that the Gilded Age concluded with (1) labor strikes and the rise of unions, (2) the stock market collapse and banking failures, with an accompanying depression between 1893-1897, and (3) new government reform and regulation.

How will we address the rise of our own income and wealth stratification, the rise of the tech billionaires and the power they wield, especially over communication and speech? And how will we reckon with continuing mass immigration and racial grievance? All of this combined with a year and a half of Covid have changed the way Americans think, how we work, and even the places we live. Woodward's insight was to realize that in the 1880 s the South was not blowing its own horn, but thoughtful Northerners-Melville, Adams, and James-realized the need to look beyond their own communities for a fresh perspective. What will be the catalyst today for the kinds of changes we will need when our Gilded Age ends? Who will shine the light on our problems today as those great American novelists did during the Gilded Age? And from what principled subculture will they draw sustenance? History suggests they could do worse that looking to the South. 